\title{
STUDI KASUS MEDIA PEMBELAJARAN MATEMATIKA BERBASIS POWER POINT KARYA MAHASISWA SEMESTER 6 PRODI PENDIDIKAN MATEMATIKA
}

\author{
Naufal Ishartono, Adi Nurcahyo \\ Universitas Muhammadiyah Surakarta, Indonesia \\ Email : ni160@ums.ac.id
}

\begin{abstract}
ABSTRAK
Matematika memiliki objek kerja yang bersifat abstrak, oleh karena itu diperlukan sebuah media pembelajaran yang dapat memvisualisasikan objek-objek abstrak dari matematika. Salah satu media visual tersebut adalah Power Point yang dapat digunakan untuk memvisualisasikan objek kerja dari matematika. Tentunya untuk menjadikan Power Point sebagai sebuah media pembelajaran matematika haruslah memenuhi kualitas media pembelajaran yang baik. Keterampilan membuat media pembelajaran yang baik inilah yang harus dimiliki oleh seorang guru matematika. Pemberian bekal keterampilan tersebut dipandang sangat penting terutama bagi mahasiswa calon guru matematika sehingga didapatkan kualitas media pembelajaran matematika berbasis Power Point yang baik. Maka perlu ada kajian terkait dengan kualitas Power Point yang dikembangkan oleh mahasiswa yang nantinya dapat menjadi bahan evaluasi perkuliahan. Oleh karena itu, penelitian ini bertujuan untuk mendeskribsikan kualitas media pembelajaran matematika berbasis Power Point yang dikembangkan oleh mahasiswa semester enam Prodi Pendidikan Matematika FKIP UMS. Kriteria yang digunakan dalam menilai kualitas tersebut adalah syarat didaktis, syarak konstruksi dan syarat teknis. Metode yang digunakan dalam penelitian ini menggunakan validasi ahli, deskripsi, dan analisis. Hasil dari penelitian ini adalah bahwa hanya 5\% dari total Power Point yang dikembangkan oleh mahasiswa memiliki kualitas yang baik. Dari 95\% sisanya, mayoritas memiliki kekurangan dalam pemenuhan syarat konstruksi. Dara fakta tersebut, kajian lebih mendalam tentang bagaimana mahasiswa dapat mengembangkan media pembealajaran matematika berbasis Power Point yang memiliki kualitas mutu yang baik dipandang perlu untuk dilakukan khusunya pada keterpenuhan syarat konstruksi.
\end{abstract}

Kata Kunci: Pendidikan Matematika, Media Pembelajaran, Power Point

\begin{abstract}
Mathematics has a work object that is abstract in nature, therefore we need a learning media that can visualize abstract objects from mathematics. One of these visual media is PowerPoint, which can be used to visualize mathematical objects. In parallel, to make PowerPoint as a learning media for mathematics, the media must meet the quality of good learning media. The skill to make good learning media is what a math teacher must have. The provision of these skills is considered very important, especially for mathematics training teachers who are directed to become professional teachers, so that the quality of mathematics learning media based on good PowerPoint is obtained. Then there needs to be a study related to the quality of PowerPoint developed by training teacher which later can be used as material for lecture evaluation. Therefore, this research aims to describe the quality of PowerPoint-based mathematics learning media developed by sixth semester students of FKIP UMS Mathematics Education Study Program. The criteria used in assessing these qualities are didactic conditions, construction conditions and technical requirements. The method used in this research uses expert validation, description, and analysis. The results of this research are that only $5 \%$ of the total PowerPoints developed by students are of good quality. Of the remaining $95 \%$, the majority have deficiencies in fulfilling construction requirements. From these facts, a more in-depth study of how students can develop PowerPoint-based mathematics learning media that have good quality is deemed necessary to be done especially in the fulfillment of construction requirements.
\end{abstract}

Keywords: Mathematics Education, Instructional Media, Power Point 


\section{PENDAHULUAN}

Penguasaan matematika menjadi salah satu aspek yang wajib diperhatikan dalam menghadapi tantangan dan isu globalisasi dalam era digital saat ini. Banyak sekali tuntutan di dunia nyata yang mewajibkan warga dunia untuk dapat menjadi solusi dari suatu masalah berdasarkan dari kemampuan matematis yang mereka miliki. Contoh dalam bidang ekonomi penguasaan matematika berpengaruh besar dalam kesuksesan siswa menguasai ilmu mikroekonomi (Ballard dkk., 2016), dalam bidang komputer dimana penguasaan matematika sangat membantu dalam pengembangan program (Borghans \& Weel, 2003), dalam ilmu kesehatan pemahaman akan bilangan membantu masyarakat dalam memahami kondisi kesehatan mereka melalui berbagai alat ukur kesehatan (Rothman, Montori, Cherrington, \& Pignone, 2014), dan masih banyak lagi manfaat penguasaan matematika di berbagai bidang.

Bagaimana dengan kondisi pemahaman matematika di Indonesia? Berdasarkan hasil laporan terakhir PISA (Programme of International Student Assessment) dan TIMSS (Trend in Mathematics and Science Study) tahun 2015 menunjukkan secara berurut bahwa tingkat literasi matematika bagi pelajar Indonesia berada pada posisi ke-63 dari 69 negara peserta PISA (www.oecd.org/pisa/) dan posisi ke-36 dari 49 negara peserta TIMSS (https:// nces.ed.gov/timss/). Hasil laporan ini tentunya haruslah direspon dengan serius oleh seluruh praktisi dan lembagalembaga pendidikan guna meningkatkan tingkat literasi matematika siswa-siswi Indonesia yang salah satu caranya adalah dengan meningkatkan kualitas proses pembelajaran matematika melalui peningkatan mutu media pembelajaran yang digunakan.

Saat ini Indonesia telah memiliki Undang-Undang No. 14 tahun 2015 tentang Guru dan Dosen dimana kedua profesi tersebut dihargai secara professional. Khusus untuk guru, profesionalisme yang dimaksud diantaranya merujuk pada profesionalisme dalam mendidik dan mengajar siswa baik di ruang kelas maupun di luar kelas (Suyanto \& Jihad, 2013). Tentunya kedua profesionalisme tersebut harus dapat ditunjang dengan kemampuan calon guru atau guru dalam menyiapkan pembelajaran yang baik, salah satunya dalam membuat media pembelajaran yang tepat untuk menyampaikan materi. Oleh karena itu Program Studi Pendidikan Matematika FKIP Universitas Muhammadiyah Surakarta memandang pentingnya untuk turut bagian dalam upaya memperbaiki kondisi tersebut dengan menyediakan mata kuliah Media Pembelajaran Matematika Berbasis Komputer untuk mahasiswa semester 6 .

$\begin{array}{lrr}\text { Dalam matakuliah } & \text { tersebut, } \\ \text { mahasiswa diajarkan } & \text { untuk } \\ \text { mengembangkan sebuah } & \text { media } \\ \text { pembelajaran matematika berbasis }\end{array}$ Power Point. Alasan pemilihan Power Point sebagai media pembelajaran utama yang harus dikuasai oleh mahasiswa Pendidikan Matematika FKIP UMS adalah dikarenakan 1) Power Point masih menjadi pilihan utama dalam membantu guru untuk memvisualkan materi ajar, 2) Power Point dapat memberikan template serta tampilan grafik yang konsisten (Keefe \& Willett, 2004), 3) meningkatkan konsentrasi siswa dalam belajar. Selain itu Xingeng \& Jianxiang (2012) merumuskan ada empat keuntungan dalam menggunakan 
PowerPoint sebagai media pembelajaran yaitu 1) efek visual yang lebih baik, 2) tingkat efisiensi yang tinggi dalam menyampaikan informasi, 3) akurat dan 4) pengetahuan dapat tersampaikan secara terstruktur. Terlebih, matematika memiliki objek kerja yang bersifat abstrak, maka diperlukan media visual untuk dapat memahami objek yang bersifat abstrak (Card dalam Jacko \& Sears, 2003).

Dalam praktiknya, penggunaan Power Point sebagai media pembelajaran tidaklah mudah dikarenakan banyak aspek yang harus diperhatikan oleh guru/ mahasiswa calon guru seperti halnya aspek kelayakan media pembelajaran, kevalidan materi matematika, dan psikologi serta kondisi siswa.

Menurut Nieven (1999) terdapat tiga aspek yang harus terpenuhi dalam mengembangkan sebuah media pembelajaran yang layak, yaitu:

1. Aspek Validitas

Aspek ini melihat dari dua hal yaitu dari kesesuaian kurikulum dan model pembelajaran dengan tujuan pengembangan, serta konsistensi dari berbagai komponen media pembelajaran yang terkait. Tentunya aspek validitas ini didasarkan pada penilaian ahli.

2. Aspek Kepraktisan

Aspek ini didasari pada pendapat guru tentang seberapa praktiskah media pembelajaran yang dikembangkan untuk dapat digunakan oleh guru dan siswa. Selain itu, aspek ini didasarkan pula pada penilaian secara teoritis tentang kepraktisan media pembelajaran yang dikembangkan.

\section{Aspek Keefektifan}

Aspek ini dapat dilihat dari: (1) hasil belajar siswa setelah menggunakan media pembelajaran yang telah dikembagkan, (2) aktivitas siswa di saat menggunakan perangkat pembelajaran, dan (3) respon siswa.

Sedangkan menurut Arsyad (2013:74), kriteria yang harus terpenuhi dalam mengembangkan media pembelajaran adalah:

1. Kesesuaian dengan tujuan

2. Kepraktisan dan keluwesan

3. Kesesuaian dengan keterampilan guru dalam penggunaannya

4. Pengelompokan sasaran

5. Mutu teknis yang dalam hal ini harus memenuhi beberapa syarat yaitu syarat didaktik, konstruksi, dan teknis (Kaligis \& Darmodjo, 1992).

Berdasarkan hasil uraian di atas, maka muncul pertanyaan penelitian yaitu seberapa baikkah kualitas media pembelajaran matematika berbasis Power Point yang dikembangkan oleh mahasiswa Prodi Pendidikan Matematika UMS yang mengambil matakuliah Media Pembelajaran Matematika Berbasis Komputer? Berdasarkan dari pertanyaan tersebut, maka penulis termotivasi untuk meneliti sejauh mana kualitas dari media pembelajaran matematika berbasis Power Point yang dikembangkan oleh mahasiswa Prodi Pendidikan Matematikfa UMS dalam mata kuliah Media Pembelajaran Matematika Berbasis Komputer. Oleh karena itu, penelitian ini hanya dibatasi pada kriteria mutu teknis yaitu pada aspek didaktik, aspek konstruksi, dan aspek teknis. 


\section{METODE}

Penelitian ini menggunakan kajian deskriptif analitis. Penelitian ini mengambil data dari Power Point hasil pengembangan mahasiswa Prodi Pendidikan Matematika FKIP UMS yang mengambil mata kuliah Media Pembelajaran Matematika Berbasis Komputer semester genap 2017/2018. Power Point yang diobservasi adalah sejumlah 43 buah dan 34 diantaranya dikerjakan secara berkelompok oleh sejumlah siswa sedangkan sisanya dikerjakan secara individu. Kemudian sejumlah Power Point tersebut dinilai oleh dosen matakuliah dan satu orang ahli media berdasarkan kriteria media pembelajaran yang baik yaitu dari syarat didaktik, syarat konstruksi, dan syarat teknis. Berikutnya, hasil penilaian dosen dan ahli media dijumlah dan dirata-rata, lalu hasilnya digunakan untuk menentukan kualitas produk pengembagan mahasiswa tersebut sesuai dengan ketiga syarat tersebut.

Ketiga syarat tersebut akan mengadopsi dari kriteria kelayakan media pembelajaran dari Kaligis dan Darmodjo (1992) dimana syarat didaktik akan berfokus pada kesesuaian isi media pembelajaran dengan kurikulum 2013 yang digunakan (kesesuaian dengan kurikulum dan ketepatan materi), syarat konstruksi akan berfokus pada kriteria Power Point seagai media pembelajaran matematika yang baik (judul menggambarkan materi, terdapat apersepsi, SK dan KD, tujuan, penjabaran materi, ilustrasi materi, contoh soal, latihan soal, dan kesimpulan), dan syarat teknis berfokus pada tata tulis dan tata letak gambar (font, ketepatan animasi, ketepatan warna, ketepatan background slide, ketepatan transisi, ketepatan penyusunan kalimat). Penilaian setiap komponen dilakukan dengan menggunakan skala Likert yang bertujuan untuk mempermudah validator dalam menentukan tingkat kesetujuannya. Adapun skala yang digunakan adalah 0 (tidak terdapat komponen), 1 (tidak sesuai), 2 (kurang sesuai), 3 (sesuai), 4 (sangat sesuai). Media pembelajaran matematika berbasis Power Point yang dikembangkan mahasiswa dikatan memiliki mutu yang baik ketika ketiga syarat tersebut memiliki nilai minimal baik yaitu dimana setiap syarat terkategorikan memenuhi. Syarat dikatakan memeuhi jika di masingmasing komponen untuk setiap syarat tidak memiliki nilai dibawah 3 .

Dari hasil penilaian tersebut, maka akan terlihat seberapa banyak produk yang telah terklasifikasikan memiliki kualitas mutu yang baik. Hasil klasifikasi data digunakan untuk menginterpretasikan kualitas dari media pembelajaran matematika berbasis Power Point yang telah dikembangkan oleh mahasiswa.

\section{HASIL DAN PEMBAHASAN}

Berikut adalah hasil penilaian mutu teknis dari ketiga syarat penilaian (syarat didaktik, syarat konstruksi, dan syarat teknis) untuk semua media pembelajaran matematika berbasis Power Point yang dikembangkan oleh mahasiswa: 


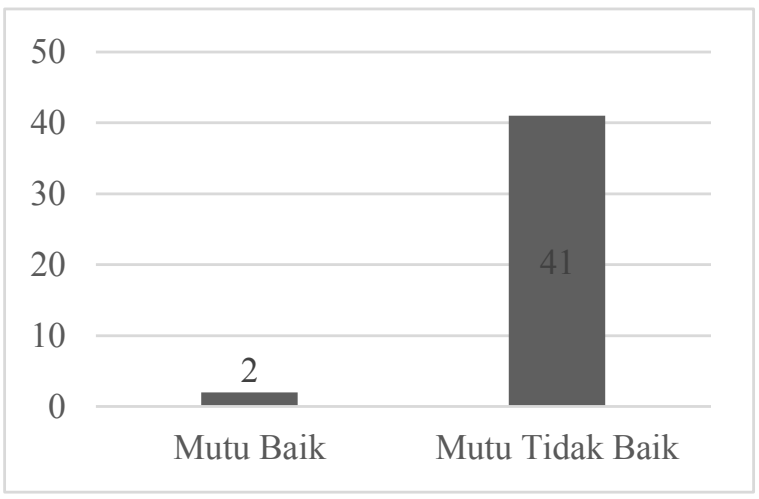

\section{Gambar 1. Hasil Penilaian Kualitas Mutu}

Dari Gambar 1, didapatkan fakta terdapat 2 Power Point yang lolos uji bahwa mayoritas Power Point yang kualitas mutu. Jika ditinjau lebih jauh, dikembangkan oleh mahasiswa tidak maka dari data tersebut dapat diperinci memiliki kualitas yang baik yaitu dari berdasarkan ketiga syarat sebagai 43 Power Point yang dinilai, hanya berikut:

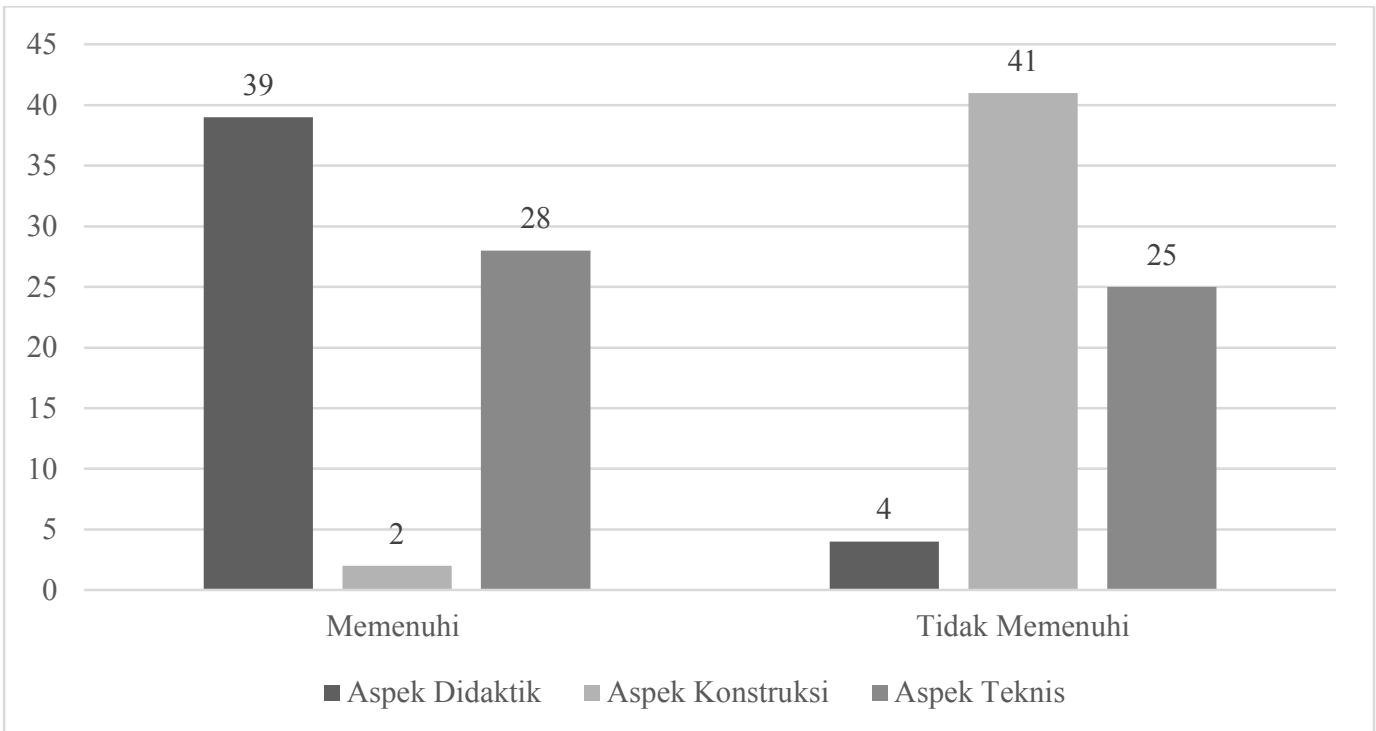

Gambar 2. Hasil Penilaian Mutu Berdasarkan Syarat Didaktis, Konstruksi dan Teknis

Gambar 2 menunjukkan bahwa dari semua media pembelajaran matematika berbasis Power Point yang dikembangkan oleh mahasiswa, kelemahan terbesar terdapat dari syarat konstruksi dimana 41 Power Point dari 43 Power Point tidak memenuhi kualitas mutu yang baik. Kelemahan berikutnya adalah pada syarat teknis dimana 25 Power Point tidak memenuhi, diikuti syarat didaktik dimana 4 Power Point tidak memenuhi. Berikut adalah rincian dari setiap syarat dan komponennya:

\section{Syarat Didaktik}

Dalam pengembangan media pembelajaran matematika, syarat didaktik harus sangat diperhatikan dikarenakan syarat ini menentukan ketepatan suatu media sebagai alat penyampaian materi. Adapun komponen dari syarat didaktik yang harus terpenuhi adalah kesesuaian media pembelajaran 
dengan kurikulum yang berlaku saat ini yaitu Kurikulum 2013, dan tingkat kevalidan materi yang dipresentasikan melalui Power Point. Berikut adalah hasil penilaian untuk syarat didaktik:

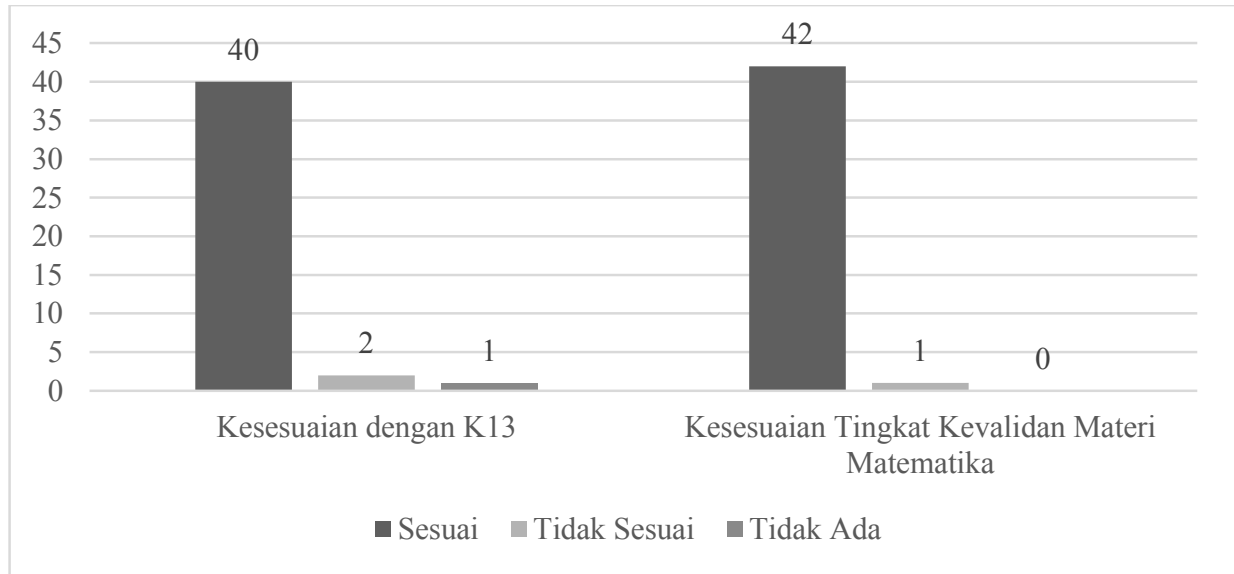

Gambar 3. Hasil Penilaian dari Syarat Didaktik

Dari Gambar 3, ditemukan bahwa sejumlah 40 Power Point memiliki kualitas didaktik yang baik dimana memenuhi kesesuaian dengan K13 dan kevalidan materi yang dibawakan. Sedangkan hanya ada 1 Power Point yang sama sekali tidak sesuai dengan K13. Hal ini menunjukkan bahwa mayoritas mahasiswa telah memahami konsep bahwa sebuah media pembelajaran harus sesuai dengan kurikulum yang digunakan saat ini di Indonesia, dan materi yang disampaikan di dalam Power Point haruslah valid sehingga informasi yang diterima oleh siswa merupakan informasi yang benar dan tidak menyesatkan.

\section{Syarat Konstruksi}

Syarat konstruksi memiliki peran yang sama pentingnya dengan syarat didaktik dimana dalam syarat ini menentukan bagaimana desain Power Point yang dikembangkan dapat membantu siswa dalam belajar. Hal yang ditekankan dalam syaratk konstruksi adalah pada bagaimana susunan slide dalam Power Point dapat membantu guru untuk menjelaskan materi secara baik, tersetruktur, terurut dengan benar sesuai urutan materi dalam kurikulum, dan tidak membingungkan atau menyulitkan siswa dalam memahami materi yang diajarkan. Berikut adalah hasil penilaian dari syarat konstruksi oleh dosen dan ahli media:

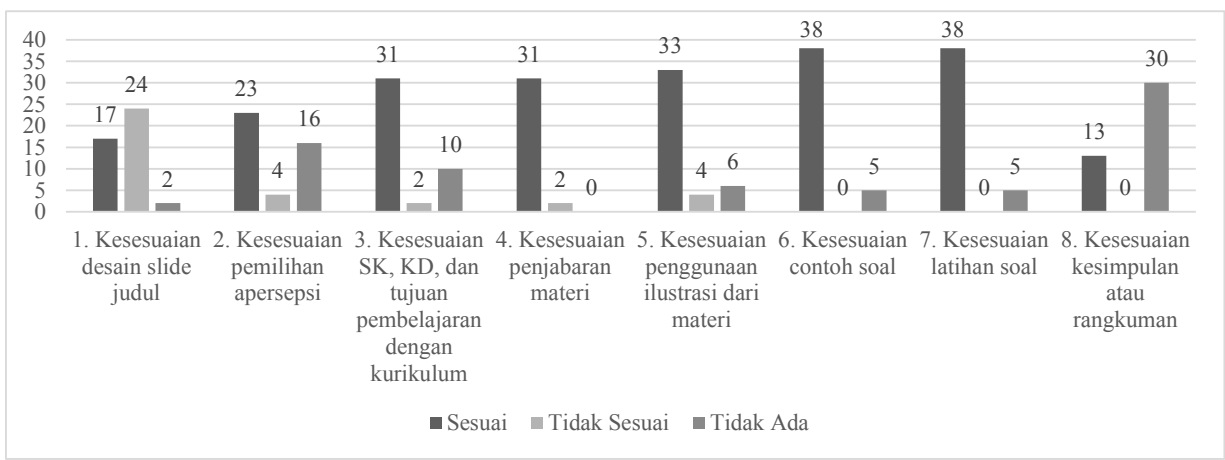

Gambar 4. Hasil Penilaian Syarat Konstruksi

JINoP (Jurnal Inovasi Pembelajaran), Volume 4, Nomor 2 , November 2018, hal 141-150 
Gambar 4 menunjukkan bahwa mayoritas media pembelajaran matematika berbasis Power Point yang dikembangkan oleh mahasiswa memiliki tingkat kesesuaian yang tinggi pada komponen ke 3, 4, 5, 6 dan 7. Sedangkan untuk komponen ke-8, yaitu terdapatnya slide kesimpulan atau rangkuman yang sesuai, adalah komponen yang memiliki tingkat kesesuaian yang paling rendah. Bukan hanya itu, pada komponen ke- 8 juga, terlihat bahwa sejumlah 30 Power Point mahasiswa tidak menyertakan slide kesimpulan atau rangkuman yang tentunya akan mempersulit siswa untuk mengingat dan memahami materi ajar yang disampaikan selama proses pembelajaran.

Berikutnya,khususuntukkomponen ke-1, yaitu terdapatnya slide judul yang sesuai dengan materi atau yang menarik perhatian siswa, menunjukkan bahwa mayoritas mahasiswa masih belum mampu membuat slide judul yang sesuai dengan materi atau dapat menarik perhatian siswa. Sebanyak 24 Power Point hanya menggunakan slide alakadarnya sehingga tidak menarik untuk diperhatikan oleh siswa. Selain itu dalam komponen tersebut, terdapat dua Power Point yang tidak menyertakan slide judul, hanya menyertakan slide yang berisi daftar nama kelompok sehingga terkategorikan bahwa slide tersebut bukanlah slide judul.

\section{Syarat Teknis}

Dalam pengembangan suatu media pembelajaran, syarat teknis sangat berkaitan pada kesesuaian pemilihan komponen-komponen yang digunakan oleh pengembang sebagai bagian dari media pembelajaran yang dikembangkan. Selain itu terpenuhinya syarat teknis akan menghindarkan media dari informasi-informasi yang bersifat ambigu. Berikut ini adalah hasil penilaian terhadap syarat teknis dari semua Power Point yang dikembangkan:

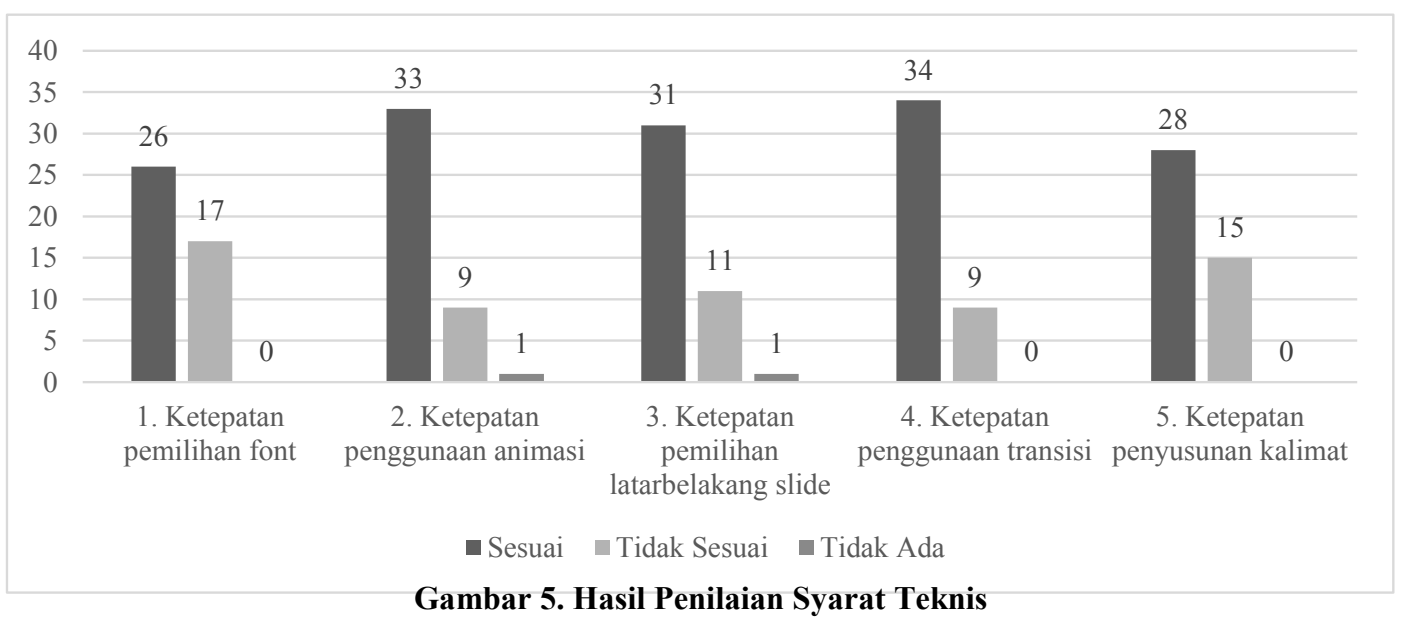

Dari Gambar 5 didapatkan hasil bahwa mayoritas Power Point yang dikembangkan oleh mahasiswa telah memenuhi syarat teknis. Bagaimanapun juga masih perlu ada beberapa komponen dari syarat teknis yang perlu diperbaiki seperti ketepatan seperti pada komponen ke-1 dan 5. Kedua komponen tersebut memiliki pengaruh yang sangat besar terhadap tingkat keterbacaan kepada siswa. Tingkat keterbacaan ini dipandang sangat penting untuk 
diperhatikan karena tingkat keterbacaan yang baik akan mempermudah pembaca untuk memahami dan mempelajari apapun yang mereka baca (Edward B, 2006).

\begin{tabular}{lccr}
\multicolumn{2}{c}{ Berdasarkan } & ketiga & syarat \\
tersebut, & maka & nampak & bahwa \\
mayoritas & Power & Point & yang
\end{tabular} dikembangkan mahasiswa telah memenuhi syarat didaktik dimana syarat tersebut sangat vital bagi semua media pembelajaran terkait dengan ketercapaian pembelajaran dan kevalidan informasi yang diberikan kepada siswa. Bagaimanapun masih terdapat beberapa syarat, yaitu syarat konstruksi dan syarat teknis, yang perlu mendapatkan perhatian kusus sebagai sebuah perbaikan dibeberapa komponennya, yaitu:

1. Slide Judul

Hampir setengah dari jumlah Power Point yang ada memiliki slide judul yang tidak menarik ataupun tidak representative sehingga mendapatkan nilai yang "kurang sesuai" atau "tidak sesuai". Desain slide judul menjadi etalase dari sebuah Power Point yang menggambarkan seperti apa isi dari Power Point yang akan digunakan, terlebih Power Point tersebut adalah sebagai bahan pembelajaran. Maka jika slide Power Point didesain menarik maka siswa cenderung akan memperhatikan slide Power Point. Sebaliknya, jika slide Power Point didesain terlalu sederhana, maka tidak akan memberikan insentif motivasi kepada siswa untuk memperhatikan materi yang diajarkan.

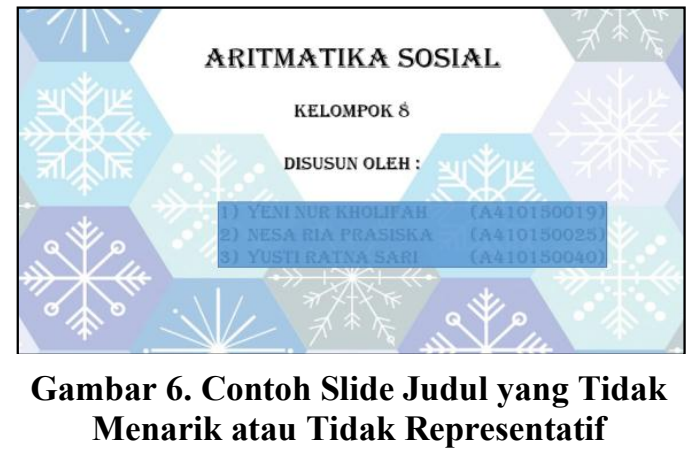

Secara desain, slide judul di atas dinilai tidak menarik dan representatif oleh dosen dan ahli media dikarenakan slide judul tidak menggambarkan isi dari topik yang akan dijelaskan yaitu Aritmatika Sosial.

2. Slide Apersepsi

Adapun yang terjadi pada slide apersepsi adalah bahwa sejumlah 16 Power Point tidak memiliki slide apersepsi. Apersepsi menurut Herbart (dalam Kim, 2016), "apperception is a term of for the assimilation of one representation or representational mass into another", atau dengan kata lain bahwa apersepsi adalah sebuah istilah untuk mengkaitkan suatu representasi dengan representasi yang lain. Artinya bahwa untuk mempelajari suatu materi yang baru, slide apersepsi dapat menjadi sebuah sarana untuk menjembatani siswa dalam mempelajari materi yang baru dengan dikaitkan dengan pengalaman atau konsep yang mereka sudah pahami/alami sebelumnya. Selain itu adanya apersepsi, pembelajaran menjadi lebih menyenangkan (Mansur, 2015). Oleh sebab itu, kealphaan 
slide apersepsi tidak dapat menambah motivasi siswa dalam belajar yang pada dasarnya sangat penting untuk diperhatikan selama proses pembelajaran.

3. Slide Rangkuman/Kesimpulan Sejumlah 43 Power Point yang dinilai oleh dosen dan ahli media, ditemukan bahwa hanya 13 Power Point yang memiliki slide kesimpulan atau rangkuman yang komprehensif. Secara teori, rangkuman atau kesimpulan memberikan kemudahan kepada pembaca untuk memahami dan mengingat materi yang telah dijelaskan sebelumnya. Seperti yang dinyatakan oleh Nordquist (2018) bahwa rangkuman bermanfaat bagi pembaca dalam memahami isi dari materi yang disampaikan. Oleh karena itu, tidak adanya slide rangkuman tidak memberikan kemudahan kepada siswa untuk mereview kembali materi apa yang telah dipelajari.

4. Ketepatan Pemilihan Font

Ketepatan pemilihan font sangat berkaitan dengan tingkat keterbacaan, sehingga ketepatan pemilihan font akan mempermudah siswa dalam membaca materi matematika yang dipresentasikan di dalam Power Point.

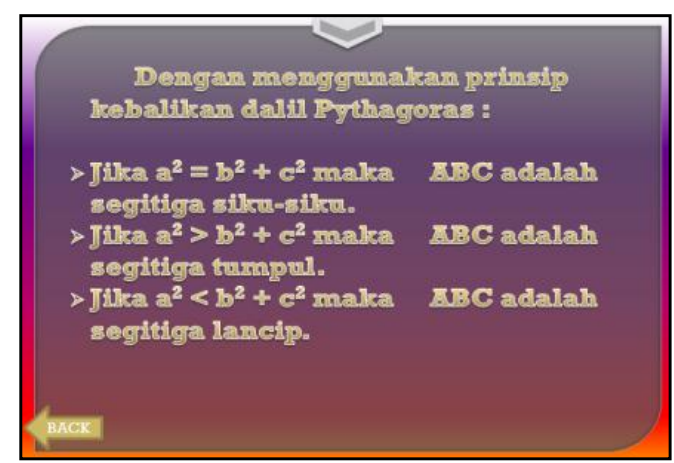

Gambar 7. Contoh Pemilihan Font yang Memiliki Tingkat Keterbacaan yang Rendah
Gambar 7 merupakan salah satu bagian dari Power Point hasil pengembangan mahasiswa yang memiliki font dengan tingkat keterbacaan yang rendah didasarkan dari penilaian dosen dan ahli media. Oleh karena itu, dikarenakan tingkat keterbacaan dipandang penting maka pemilihan font pun juga dipandang penting.

5. Ketepantan Penyusunan Kalimat

Dari 43 Power Point yang dinilai terdapat 15 Power Point yang memiliki kualitas penyusunan kalimat yang tidak sesuai. Hal ini dipandang perlu untuk mendapatkan perhatian lebih dikarenakan penyusunan kalimat, sama halnya dengan pemilihan font, berpengaruh terhadap tingkat keterbacaan. Jika tingkat keterbacaan tidak memenuhi, maka siswa akan kesulitan dalam memahami materi yang diberikan melalui Power Point.

\section{SIMPULAN}

Berdasarkan dari penilaian dosen dan ahli media, media pembelajaran matematika berbasis Power Point yang dikembangkan belum memiliki kualitas mutu yang baik dimana hanya 2 dari 43 Power Point yang memenuhi ketiga syarat mutu media pembelajaran yang baik yaitu syarat didaktik, syarat konstruksi, dan syarat teknis. Dari 41 Power Point yang tidak memiliki kualitas mutu yang baik, mayoritas syarat yang tidak terpenuhi adalah pada syarat konstruksi terutama pada komponen slide judul, slide kesimpulan, dan slide apersepsi.

Keterpenuhan syarat konstruksi dalam pengembangan Power Point sebagai media pembelajaran matematika memang cukup sulit 
untuk dikembangkan oleh mahasiswa dikarenakan ketiga komponen tersebut memerlukan tingkat pemahaman yang tinggi terkait dengan materi yang akan disampaikan di dalam Power Point. Oleh karena itu, kajian lebih mendalam tentang bagaimana mahasiswa dapat mengembangkan media pembealajaran matematika berbasis Power Point yang memiliki kualitas mutu yang baik dipandang perlu untuk dilakukan.

\section{DAFTAR PUSTAKA}

Arsyad, A.(2013). Media Pembelajaran. Jakarta: Rajawali Press.

Ballard, C. L., Johnson, M. F., The, S., Education, E., Winter, N., Taylor, P., ... Johnson, M. F. (2016). Basic Math Skills and Performance in an Introductory Economics Class. The Journal of Economics Education, 35(1), 3-23.

Borghans, L., \& Weel, B. ter. (2003). Are Computer Skills the New Basic Skills? The Returns to Computer, Writing and Math Skills in Britain (No. 751). Bonn.

Edward B, F. (2006). "Readability." Reading Hall of Fame Book. Newark, DE: International Reading Association.

Jacko, J. A., \& Sears, A. (2003). Computer support for learning mathematics: A learning environment based on recreational learning objects. Computers \& Education, 48(4), 618-641.

Kaligis, J. R. E., \& Darmodjo, H. (1992). Pendidikan IPA II. Jakarta: Depdikbud.

Keefe, D. D., \& Willett, J. D. (2004). Points of View Power Point in the Classroom. Cell Biology Education, 3(3), 156-158. https:// doi.org/10.1187/cbe.04-06-0045
Kim, A. (2016). Johann Friedrich Herbart. Retrieved September 11, 2018, from https://plato.stanford. edu/entries/johann-herbart/

Mansur, H. (2015). Menciptakan Pembelajaran Efektif Melalui Apersepsi. LPMP Sulsel. Retrieved from http://www.lpmpsulsel. net/v2/index.php?option $=$ com content\&view $=$ article $\&$ id $=327$ : pembelajaran-efektifapersepsi\&\% 0 Acatid $=42$ : ebuletin\&Itemid $=215$

Nieven, N. (1999). Prototyping to Reach Product Quality. Dordrecht: Kluwer Academic Publishers.

Nordquist, R. (2018). Summary (Composition). Glossary of Grammatical and Rhetorical Terms. Retrieved September 13, 2018, from https://www.thoughtco.com/ summary-composition-1692160

Rothman, R. L., Montori, V. M., Cherrington, A., \& Pignone, M. P. (2014). Journal of Health Communication : International Perspectives Perspective: The Role of Numeracy in Health Care. Journal of Health Communication, 13(6), 583-595. https://doi. org/10.1080/10810730802281791

Suyanto, \& Jihad, A. (2013). Menjadi Guru Profesional. Jakarta: Penerbit Erlangga.

Xingeng, D., \& Jianxiang, L. (2012). Advantages and Disadvantages of Power Point in Lectures to Science Students. International Journal of Education and Management Engineering, 9, 61-65. https://doi. org/10.5815/ijeme. 2012.09.10 